\title{
STUDIES ON THE HYPOANEUPLOIDS OF COMMON WHEAT. I. DOUBLE MONOSOMICS AND TRIPLE MONOSOMICS")
}

\author{
SHŌJI SHIGENAGA \\ Exprrimental Farm, Kyoto University, Takatsuki, Osaka
}

Received December 21, 1967

Since Sears (1954) has established the complete series of monosomics and nullisomics in common wheat, they proved to have been greatly important not only in fundamental study of phylogenetic problems but also in practical aspect for wheat breeding. It is attributed to the hexaploid nature of common wheat $(2 n=42)$ that such aneuploids as monosomics or nullisomics are viable.

Sears (1954) reported spontaneous occurrence of hypoaneuploids with less chromosome number than 40 in some offspring of self-pollinated nullisomics. However, no further studies of these hypoaneuploids have beən carried out.

Several wheat workers studied in detail various hypoaneuploids which were obtained in the progenies of pentaploid Triticum-hybrids (Wakakuwa 1929, Kihara and Matsumura 1942, et al.). All these hypoaneuploids were originated from interspecific crosses. Therefore, they did not always give an unequivocal picture of the characteristics attributable to specific chromosomes of common wheat.

Mochizuki and Shigenaga (1964) devised a theoretic procedure for intentional elimination of any given chromosome from common wheat by using nullisomic lines. By this method, the author was successful to obtain various hypoaneuploids in Chinese Spring wheat. In this paper, the procedure for production of double and triple monosomics, and their morphological characteristics and chromosome behavior will be presented.

In this experiment, the author intended to obtain various hypoaneuploids deficient for A genome chromosomes in Chinese Spring. After Sears (1958), Okamoto (1962) and Chapman and Riley (1966), the chromosome XIV, II, XII, IV, IX, VI and XI were belonged to $\mathrm{A}$ genome, being designated as chromosome $1 \mathrm{~A}, 2 \mathrm{~A}, 3 \mathrm{~A}, 4 \mathrm{~A}, 5 \mathrm{~A}, 6 \mathrm{~A}$ and $7 \mathrm{~A}$, respectively. However, at the beginning of this experiment, the chromosome XIII was considered as chromosome 2A (Sears 1958, Okamoto 1962). Therefore, the hypoaneuploids involving chromosome $2 \mathrm{~B}$ (XIII) were also dealt in this experiment.

\section{MATERIALS AND METHODS}

Eight nullisomics, which were selected in the progenies of self-pollinated monosomics of Triticum aestivum L. emend Thell. ssp. vulgare cultivar Chinese Spring, were

1) A part of the thesis submitted to Kyoto University in partial fulfillment of the requirements for D. A. degree. The present study was partly supported by a grant from the Scientific Research Fund of the Ministry of Education. 
primarily used for the production of double and triple monosomics. Nulli-1A, nulli-3A, nulli-5A, nulli-6A and nulli-7A had both male and female fertilities, so that they could be propagated by self-pollination.

Nulli-2A was female sterile. For obtaining a large number of nulli-2A, crosses between mono-2A(ㅇ) and nulli-2A(令) were made: About 75 per cent of the $\mathrm{F}_{1}$ 's were nullisomic.

Nulli-4A was male sterile, a large number of which, however, could be obtained in the self-pollinated progeny of mono-isosomic- $4 \Lambda$ (given by Dr. E. R. Sears) at so high frequency as 32 per cent.

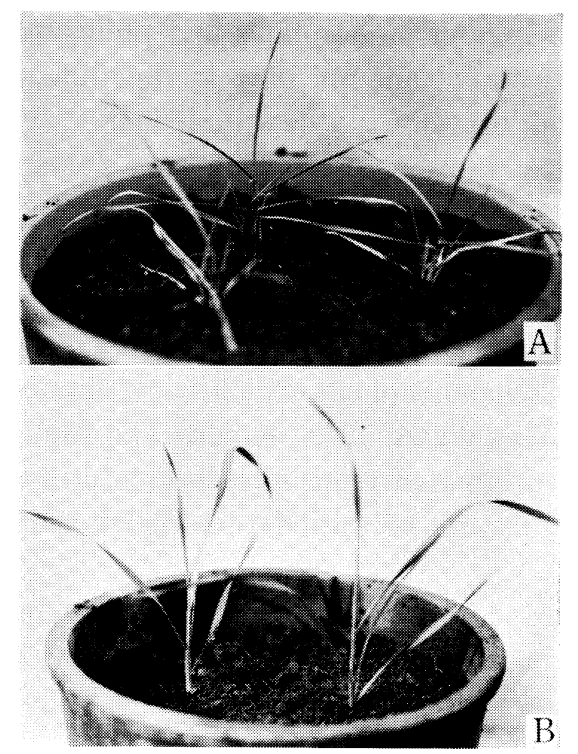

Fig. 1. Seedlings of (A) nulli-2B and (B) the normal in Chinese Spring wheat.
Nulli-2B was female fertile, but the anthers did not dehisce. However, they were selected with a comparative ease among seedlings which grew from selfed seeds of mono-2B by certain morphological characteristics, i.e. dwarfness, slender leaves and rapid tillering (Fig. 1).

Thus, a number of nullisomics became available for the intentional elimination of given chromosomes from hexaploid wheat. Typical spikes of the nullisomics used in this experiment are shown in Fig. 2.

Each hypoaneuploid involved in the present investigation was symbolized for brevity with letter $\mathrm{m}$ or $\mathrm{n}$ (indicating monosomic and nullisomic condition, respectively) and the chromosome deficient in it. Some examples are given as

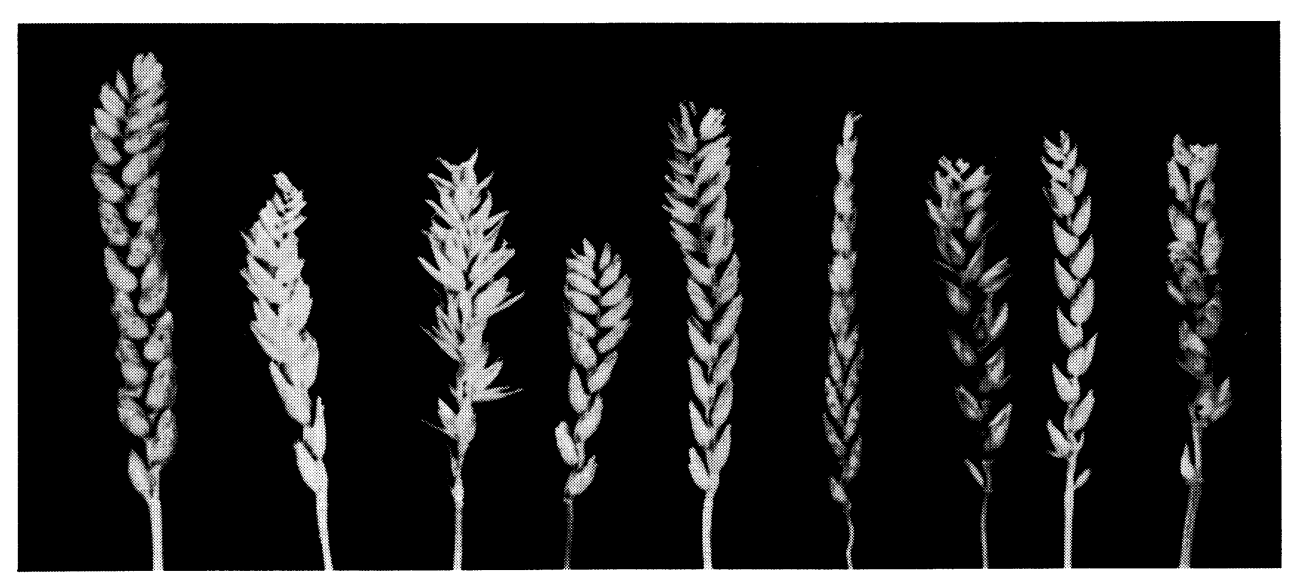

Fig. 2. Spikes of Chinese Spring nullisomics, which were used in crosses. From left to right; normal, n1A, n2B, n3A, n4A, n5A, n6A, n7A and n2A. 
follows :

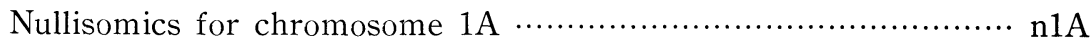

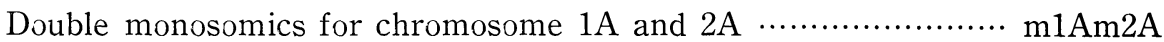

Triple monosomics for chromosome $1 \mathrm{~A} .2 \mathrm{~A}$ and $3 \mathrm{~A} \ldots \ldots \ldots \ldots \ldots . . . . . \mathrm{m} 1 \mathrm{Am} 2 \mathrm{Am} 3 \mathrm{~A}$

For producing double monosomics, two different nullisomics were crossed; male sterile nulli-4A and nulli-2B were always used as the female parent, and, on the other hand, female sterile nulli-2A as the pollen parent. The $F_{1}$ hybrids were examined their chromosome number in root-tip mitosis and chromosome configuration in PMC's meiosis.

Double monosomics produced by the above-mentioned procedure were crossed to third nullisomic in order to obtain triple monosomics. Resulted hybrid plants were examined their chromosome number; those with 39 chromosomes in root-tip cells were selected, and chromosome configuration in their meiosis was studied. The procedure for producing a double monosomic for chromosomes $1 \mathrm{~A}$ and $2 \mathrm{~A}$ and a triple monosomic for $1 \mathrm{~A}, 2 \mathrm{~A}$ and $3 \mathrm{~A}$ is shown in Fig. 3 as an example.

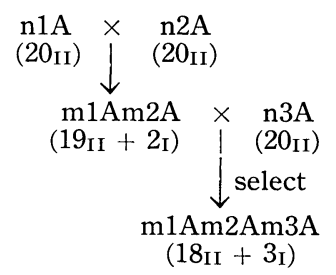

Fig. 3. Example of the procedure for producing a double monosomic and triple monosomic from pre-existing nullisomics. Chromosome configuration at $\mathrm{MI}$ in meiosis of each plant is shown in parentheses.

The somatic and meiotic chromosomes of all individuals involved in this experiment were observed with temporary slides prepared by aceto-carmine squash method.

\section{RESULTS}

\section{A. Double monosomics}

Crosses were made in eight combinations, namely, between $\mathrm{n} 2 \mathrm{~B}$ and $\mathrm{n} 1 \mathrm{~A}, \mathrm{n} 1 \mathrm{~A}$ and $\mathrm{n} 2 \mathrm{~A}, \mathrm{n} 1 \mathrm{~A}$ and $\mathrm{n} 7 \mathrm{~A}, \mathrm{n} 3 \mathrm{~A}$ and $\mathrm{n} 6 \mathrm{~A}, \mathrm{n} 7 \mathrm{~A}$ and $\mathrm{n} 3 \mathrm{~A}, \mathrm{n} 4 \mathrm{~A}$ and $\mathrm{n} 5 \mathrm{~A}, \mathrm{n} 4 \mathrm{~A}$ and $\mathrm{n} 2 \mathrm{~A}$, and n5A and n6A. Seed-setting rates of those crosses varied from 5.9 per cent in $n 4 A \times n 2 A$ to 42.0 per cent in $\mathrm{n} 2 \mathrm{~B} \times \mathrm{n} 1 \mathrm{~A}$. Seeds obtained from all crosses were indistinguishable from the normal ones in appearance. All of them were allowed to germinate on wet filter paper in petri dishes; their germination rates were high, ranging from 75 to 100 per cent. The somatic chromosome numbers of the $F_{1}$ plants were mostly 40 , though a few plants had 39,41 or $40+2$ f chromosomes, $\mathrm{f}$ indicating a telocentric.

Chromosome configuration at the first meiotic metaphase of the $F_{1}$ plants with 40 somatic chromosomes was observed. The results are given in Table 1, which indicate that the configuration of $19_{\Perp}+2_{\text {I }}$ (Fig. 4) was observed at pronouncedly high frequency in all $F_{1}$ hybrids irrespective of the cross combinations. Thus, these $F_{1}$ plants should be called double monosomic and were designated by m1Am2B, m1Am2A, m1Am7A, m3Am6A, m3Am7A, m4Am5A, m2Am4A, and m5Am6A.

The configuration of $18_{\|}+4$, was also observed in a few pollen mother cells without exception. The configuration of $17_{\|}+6_{\text {I }}$ was observed in some pollen mother cells of m3Am6A, m4Am5A and m5Am6A. Two univalents in the configuration of $19_{I}+2_{I}$ 
Table 1. Frequencies in per cent of various chromosome configurations at MI in eight kinds of double monosomics of Chinese Spring wheat

\begin{tabular}{c|c|ccc}
\hline \hline \multirow{2}{*}{$\begin{array}{c}\text { Double } \\
\text { monosomics }\end{array}$} & $\begin{array}{c}\text { No. cells } \\
\text { observed }\end{array}$ & $19_{\text {II }}+2_{\text {I }}$ & $18_{\text {I }}+4_{\text {I }}$ & $17_{\text {II }}+6_{\text {I }}$ \\
\cline { 2 - 5 } m1Am2B & 117 & 96.6 & 3.4 & - \\
m1Am2A & 100 & 95.0 & 5.0 & - \\
m1Am7A & 125 & 96.0 & 4.0 & - \\
m3Am6A & 125 & 93.6 & 4.8 & 1.6 \\
m3Am7A & 102 & 97.1 & 2.9 & - \\
m4Am5A & 100 & 93.0 & 6.0 & 1.0 \\
m2Am4A & 100 & 94.0 & 6.0 & - \\
m5Am6A & 106 & 92.5 & 6.6 & 0.9 \\
\hline
\end{tabular}

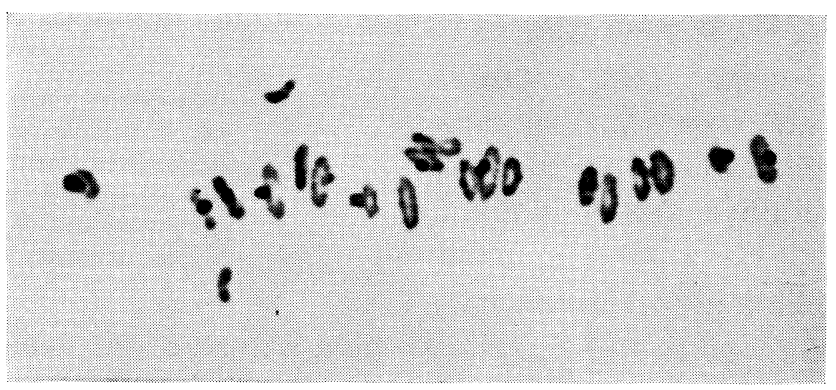

Fig. 4. A first meiotic metaphase plate, showing $19_{[}+2_{[}$, of a double monosomic m1Am2B of Chinese Spring wheat. (ca. $900 \times$ ).

should be non-homologous with each other. On the contrary, two additional univalents in the configuration of $18_{\mathbb{I}}+4_{\mathbb{I}}$ and four in the configuration of $17_{\mathbb{I}}+6_{\mathbb{I}}$ must be homologous in pairs, which failed spontaneously to pair. There seems to be no difference between the eight double monosomics as to the frequency of univalents derived from unpairing of homologous chromosomes.

Growth of all double monosomics was mostly normal. At maturity, however, the plant height and number of tillers were reduced to some extent compared with those of the normal. The fertility was also reduced to about 51 per cent of the normal. Culms of $\mathrm{m} 1 \mathrm{Am} 2 \mathrm{~A}$ and $\mathrm{m} 2 \mathrm{Am} 4 \mathrm{~A}$ were thicker than those of the normal (Table 2); it may be an effect of deficiency of a $2 \mathrm{~A}$ chromosome, because $\mathrm{n} 2 \mathrm{~A}$ has very thick culms.

Characteristics of the spikes of double monosomics were more or less affected by deficiency of the particular chromosomes. The most conspicuous was the effect of $5 \mathrm{~A}$ chromosome, whose deficiency caused deformation of the spike of Chinese Spring wheat (square head) to speltoid type regardless of what is the second deficient chromosome. The representative spikes of eight double monosomics are shown in Fig. 5.

B. Triple monosomics

Crosses between double monosomics and nullisomics were made in two directions, i.e., double monosomics were used both as male and female parents. Seeds obtained 
Table 2. Some characteristics at maturity of eight kinds of double monosomics in Chinese Spring wheat

\begin{tabular}{|c|c|c|c|c|c|}
\hline $\begin{array}{c}\text { Double } \\
\text { monosomics }\end{array}$ & $\begin{array}{l}\text { No. plants } \\
\text { examined }\end{array}$ & $\begin{array}{l}\text { Plant } \\
\text { height } \\
(\mathrm{cm})\end{array}$ & $\begin{array}{l}\text { No. } \\
\text { tillers }\end{array}$ & $\begin{array}{l}\text { Culm } \\
\text { diam. } \\
(\mathrm{mm})\end{array}$ & $\underbrace{\text { No. seeds }}_{\text {spike }}$ \\
\hline $\mathrm{m} 1 \mathrm{Am} 2 \mathrm{~B}$ & 16 & $\begin{array}{l}114.8 \\
(87.5)\end{array}$ & $\begin{array}{c}25.7 \\
(73.9)\end{array}$ & $\begin{array}{c}2.0 \\
(100.0)\end{array}$ & $\begin{array}{c}27.6 \\
(38.5)\end{array}$ \\
\hline $\mathrm{m} 1 \mathrm{Am} 2 \mathrm{~A}$ & 13 & $\begin{array}{l}110.0 \\
(83.8)\end{array}$ & $\begin{array}{c}31.7 \\
(91.1)\end{array}$ & $\begin{array}{c}2.7 \\
(135.0)\end{array}$ & $\begin{array}{c}53.8 \\
(75.0)\end{array}$ \\
\hline $\mathrm{m} 1 \mathrm{Am} 7 \mathrm{~A}$ & 8 & $\begin{array}{l}103.3 \\
(82.5)\end{array}$ & $\begin{array}{c}21.9 \\
(62.9)\end{array}$ & $\begin{array}{c}1.7 \\
(85.0)\end{array}$ & $\begin{array}{c}27.0 \\
(37.7)\end{array}$ \\
\hline $\mathrm{m} 3 \mathrm{Am} 6 \mathrm{~A}$ & 7 & $\begin{array}{l}117.0 \\
(89.2)\end{array}$ & $\begin{array}{c}27.1 \\
(77.9)\end{array}$ & $\begin{array}{c}1.6 \\
(80.0)\end{array}$ & $\begin{array}{c}36.5 \\
(50.9)\end{array}$ \\
\hline $\mathrm{m} 3 \mathrm{Am} 7 \mathrm{~A}$ & 8 & $\begin{array}{l}107.1 \\
(81.6)\end{array}$ & $\begin{array}{c}21.6 \\
(62.1)\end{array}$ & $\begin{array}{c}1.8 \\
(90.0)\end{array}$ & $\begin{array}{c}33.7 \\
(47.0)\end{array}$ \\
\hline $\mathrm{m} 4 \mathrm{Am} 5 \mathrm{~A}$ & 14 & $\begin{array}{l}127.3 \\
(97.0)\end{array}$ & $\begin{array}{c}25.5 \\
(73.3)\end{array}$ & $\begin{array}{c}2.0 \\
(100.0)\end{array}$ & $\begin{array}{c}24.2 \\
(33.8)\end{array}$ \\
\hline $\mathrm{m} 2 \mathrm{Am} 4 \mathrm{~A}$ & 6 & $\begin{array}{l}107.6 \\
(82.0)\end{array}$ & $\begin{array}{c}25.7 \\
(73.9)\end{array}$ & $\begin{array}{c}2.8 \\
(140.0)\end{array}$ & $\begin{array}{c}35.3 \\
(49.2)\end{array}$ \\
\hline $\mathrm{m} 5 \mathrm{Am} 6 \mathrm{~A}$ & 6 & $\begin{array}{l}130.0 \\
(99.1)\end{array}$ & $\begin{array}{c}31.8 \\
(91.4)\end{array}$ & $\begin{array}{c}2.0 \\
(100.0)\end{array}$ & $\begin{array}{c}54.9 \\
(76.6)\end{array}$ \\
\hline Mean & 9.8 & $\begin{array}{l}115.3 \\
(87.8)\end{array}$ & $\begin{array}{c}26.4 \\
(75.8)\end{array}$ & $\begin{array}{c}2.1 \\
(103.8)\end{array}$ & $\begin{array}{c}36.6 \\
(51.1)\end{array}$ \\
\hline
\end{tabular}

Note: 1) Culm diameter was measured at $5 \mathrm{~cm}$ below the spike neck.

2) Seeds were set by self-pollination.

3) Figure in parentheses gives an index of the measurement of various double monosomics in comparison with that of normal Chinese Spring wheat as 100 .

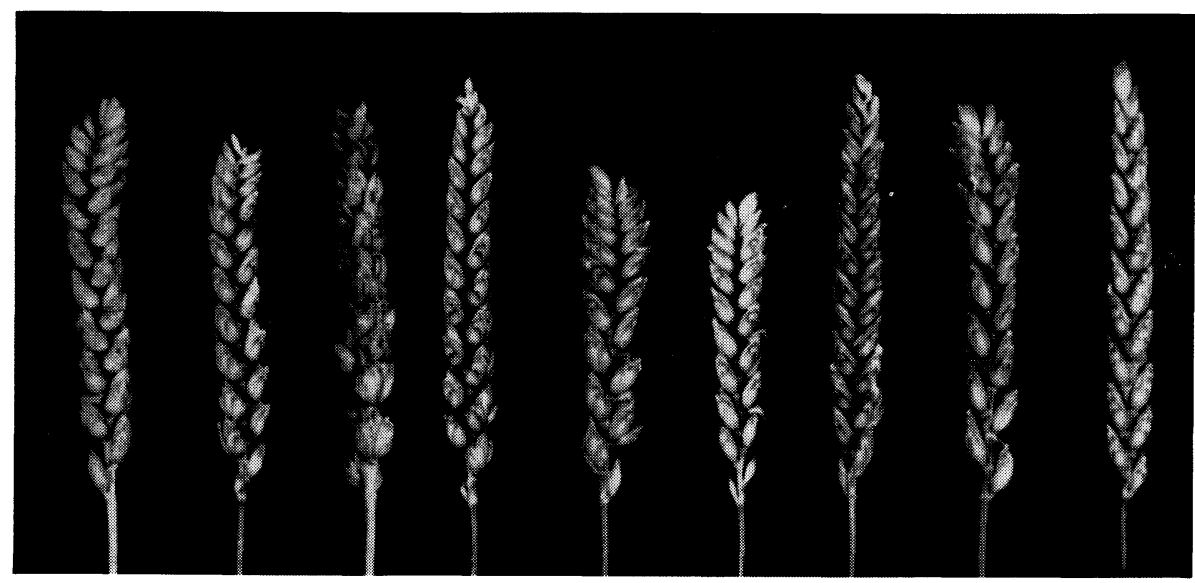

Fig. 5. Spikes of double monosomics in Chinese Spring wheat. From left to right; normal, m1Am2B, m1Am2A, m1Am7A, m3Am6A, m3Am7A, m4Am5A, m2Am4A and m5Am6A.

from the two cross directions were indistinguishable in appearance from each other. The germination rate of the seeds from the cross, double monosomics $(+q) \times$ nullisomics ( $\hat{\delta})$, was 81.8 per cent on the average, varying from 75.0 to 86.7 per cent, and that of the cross, nullisomics $($ ㅇ $) \times$ double monosomics $(\hat{o})$, was 58.2 per cent on the average, 
ranging from 54.4 to 61.1 per cent. Thus, the former cross combination gave apparently more viable seeds than the latter.

The somatic chromosome numbers of the $F_{1}$ plants produced from the crosses between double monosomics and nullisomics varied from 39 to 41 . As shown in Table 3, about 50 per cent of the plants had 39 chromosomes and less than 20 per cent 41 chromosomes, when double monosomics were used as female parent. On the other hand, the frequency of 39-chromosome plants was only about four per cent and that of 41 chromosome plants went up to more than 80 per cent, when double monosomics were used as male parent.

Table 3. Number of plants with different chromosome numbers in the $F_{1}$ of the cross, double monosomics $\times$ nullisomics, in Chinese Spring wheat

\begin{tabular}{|c|c|c|c|c|c|}
\hline \multirow{2}{*}{$\begin{array}{l}\text { Cross } \\
\text { combinations } \\
\text { (우) (令) }\end{array}$} & \multicolumn{4}{|c|}{ Chromosome numbers } & \multirow{2}{*}{ Total } \\
\hline & 39 & 40 & 41 & $41+1 f^{*}$ & \\
\hline $\mathrm{n} 4 \mathrm{~A} \times \underset{(\%)}{\operatorname{m} 1 \mathrm{Am}} 2 \mathrm{~B}$ & $\stackrel{2}{(4.1)}$ & $\begin{array}{c}5 \\
(10.2)\end{array}$ & $\begin{array}{c}41 \\
(83.7)\end{array}$ & $\begin{array}{c}1 \\
(2.0)\end{array}$ & $\begin{array}{c}49 \\
(100)\end{array}$ \\
\hline $\mathrm{n} 4 \mathrm{~A} \times \underset{(\%)}{\operatorname{m} 5 \mathrm{Am}} 6 \mathrm{~A}$ & $\begin{array}{c}2 \\
(3.7)\end{array}$ & $\begin{array}{c}3 \\
(5.6)\end{array}$ & $\begin{array}{c}49 \\
(90.7)\end{array}$ & - & $\begin{array}{c}54 \\
(100)\end{array}$ \\
\hline $\mathrm{n} 7 \mathrm{~A} \times \underset{(\%)}{\operatorname{m} 1 \mathrm{Am} 2 \mathrm{~B}}$ & $\begin{array}{c}5 \\
(3.6)\end{array}$ & $\begin{array}{l}11 \\
(8.0)\end{array}$ & $\begin{array}{l}122 \\
(88.4)\end{array}$ & - & $\begin{array}{c}138 \\
(100)\end{array}$ \\
\hline$\underset{(\%)}{\operatorname{m} 1 \mathrm{Am} 2 \mathrm{~B} \times \mathrm{n} 7 \mathrm{~A}}$ & $\begin{array}{c}14 \\
(53.9)\end{array}$ & $\begin{array}{c}9 \\
(34.6)\end{array}$ & $\begin{array}{c}3 \\
(11.5)\end{array}$ & - & $\begin{array}{c}26 \\
(100)\end{array}$ \\
\hline$\underset{(\%)}{\operatorname{m} 3 \mathrm{Am} 7 \mathrm{~A} \times \mathrm{n} 1 \mathrm{~A}}$ & $\begin{array}{c}14 \\
(45.2)\end{array}$ & $\begin{array}{c}11 \\
(35.5)\end{array}$ & $\begin{array}{c}6 \\
(19.3)\end{array}$ & - & $\begin{array}{c}31 \\
(100)\end{array}$ \\
\hline$\underset{(\%)}{\operatorname{m} 1 \mathrm{Am} 7 \mathrm{~A}} \times \mathrm{n} 6 \mathrm{~A}$ & $\begin{array}{c}12 \\
(50.0)\end{array}$ & $\begin{array}{c}8 \\
(33.3)\end{array}$ & $\begin{array}{c}4 \\
(16.7)\end{array}$ & - & $\begin{array}{c}24 \\
(100)\end{array}$ \\
\hline
\end{tabular}

* f indicates a telocentric chromosome.

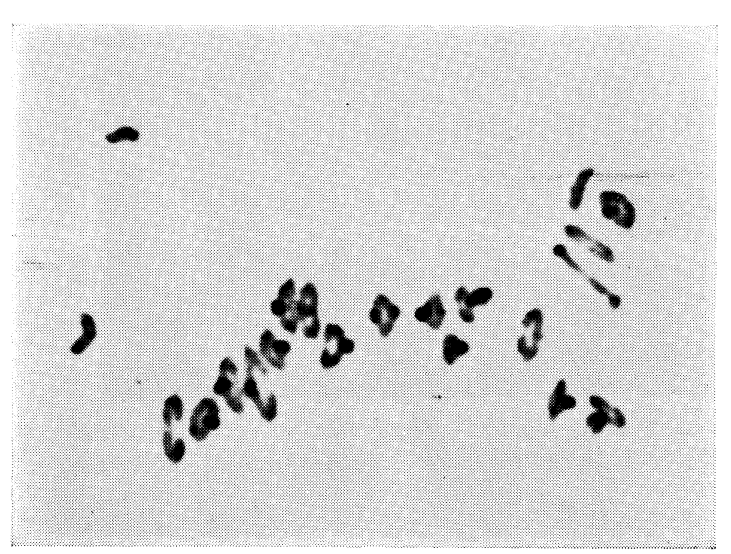

Fig. 6. A first meiotic metaphase plate, showing $18 \mathrm{I}$, in a triple monosomic m1Am2B$\mathrm{m} 4 \mathrm{~A}$ of Chinese Spring wheat. (ca. 1,000×).
Chromosome configuration observed at first meiotic metaphase of 39-chromosome plants was all $18_{\text {I }}+$ $3_{\text {I }}$ (Fig. 6). Thus, these plants should be considered as triple monosomics, which have three different chromosomes in single dose. The author could obtain five triple monosomics, m1Am2Bm4A, m1Am2Bm7A, m4Am5Am6A, m1Am3Am7A, and m1Am6Am7A.

The triple monosomics grew almost normally. However, they headed somewhat later than the normal. Their plant height, number of tillers, culm diameter, and number of seeds 
Table 4. Some characteristics at maturity of five kinds of triple monosomics in Chinese Spring wheat

\begin{tabular}{c|c|cccc}
\hline \hline $\begin{array}{c}\text { Triple } \\
\text { monosomics }\end{array}$ & $\begin{array}{c}\text { No. plants } \\
\text { examined }\end{array}$ & $\begin{array}{c}\text { Plant } \\
\text { height } \\
(\mathrm{cm})\end{array}$ & $\begin{array}{c}\text { No. } \\
\text { tillers }\end{array}$ & $\begin{array}{c}\text { Culm } \\
\text { diam. } \\
(\mathrm{mm})\end{array}$ & $\begin{array}{c}\text { No. seeds } \\
\text { spike }\end{array}$ \\
\hline m1Am2Bm4A & 2 & 82.0 & 8.0 & 2.0 & 20.9 \\
m1Am2Bm7A & 19 & $(62.5)$ & $(23.0)$ & $(100.0)$ & $(29.1)$ \\
m4Am5Am6A & 2 & 87.3 & 11.1 & 1.9 & 35.2 \\
m1Am3Am7A & \multirow{2}{*}{14} & 124.0 & $(31.9)$ & $(95.0)$ & $(49.1)$ \\
m1Am6Am7A & \multirow{2}{*}{12} & $(94.5)$ & $(40.2)$ & $(95.0)$ & $(19.8)$ \\
& & 95.0 & 11.1 & 2.0 & 23.1 \\
Mean & \multirow{2}{*}{$9.4)$} & $(31.9)$ & $(100.0)$ & $(32.2)$ \\
& \multirow{2}{*}{9.8} & $(69.4)$ & $(37.4)$ & $(100.0)$ & $(39.1)$ \\
\hline
\end{tabular}

Note: 1) Culm diameter was measured at $5 \mathrm{~cm}$ below the spike neck.

2) Seeds were set by self-pollination.

3) Figure in parentheses gives an index of the measurement of various triple monosomics in comparison with that of normal Chinese Spring wheat as 100.

per spike at the time of maturity are shown in Table 4.

The results indicate that the vigor and fertility of the triple monosomics were undoubtedly reduced comparing to those of the normal. Spikes of the triple monosomics, $\mathrm{m} 1 \mathrm{Am} 2 \mathrm{Bm} 4 \mathrm{~A}$ and $\mathrm{m} 4 \mathrm{Am} 5 \mathrm{Am} 6 \mathrm{~A}$, were rather longer than that of the normal plant.

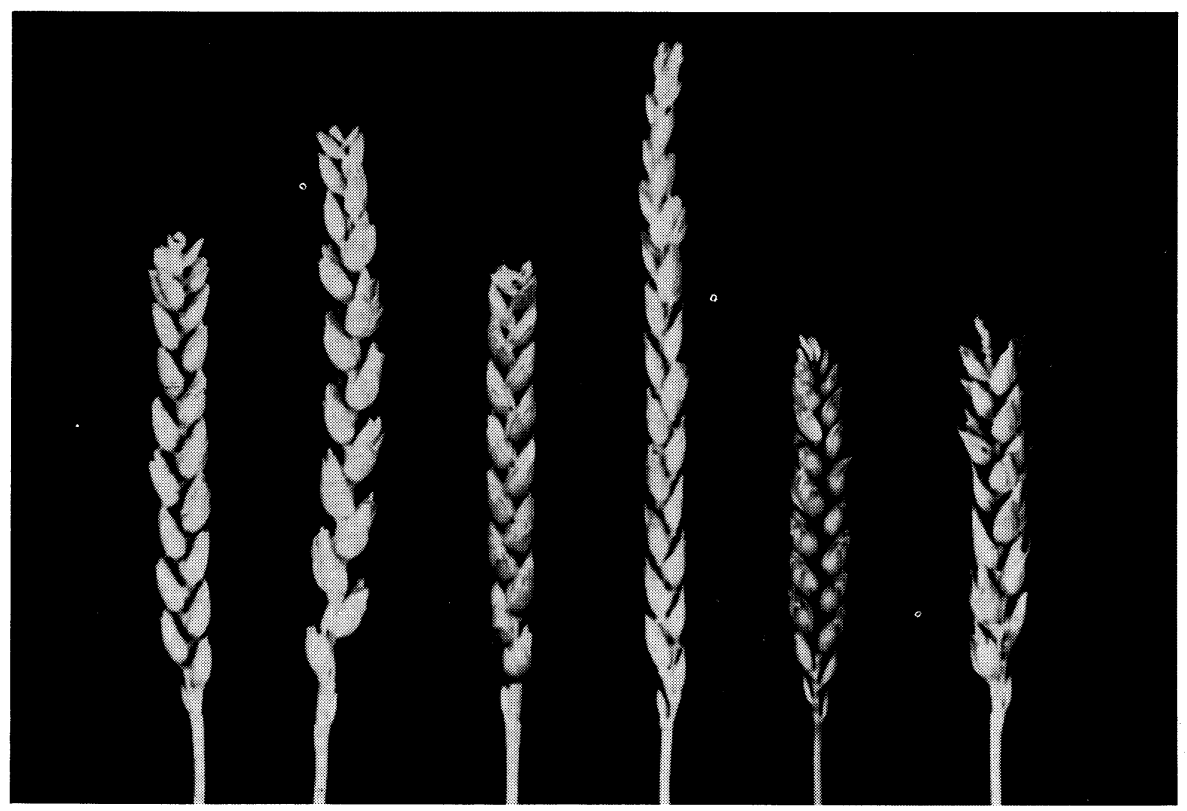

Fig. 7. Spikes of triple monosomics in Chinese Spring wheat. From left to right; normal, m1Am2Bm4A, m1Am2Bm7A, m4Am5Am6A, m1Am3Am7A and m1Am6Am7A. 
Other triple monosomics had, on the other hand, somewhat smaller spikes than the normal. Of these five triple monosomics, only m4Am5Am6A had the speltoid spike. A representative spike of each triple monosomic is shown in Fig. 7.

To maintain those triple monosomic strains, they were pollinated by normal pollen grains, and in their progenies plants with 39 chromosomes in somatic cells, showing $18_{\text {I }}+3_{\text {I }}$ configuration in the first meiotic metaphase were selected. In this cross, seedsetting rate of the triple monosomics was ranged from 60.3 to 65.7 per cent and the germination rate of the $F_{1}$ seeds from 80.0 to 86.7 per cent.

Chromosome number of the $F_{1}$ plants varied from $2 n=39$ to $2 n=42$, and the frequency of the plants with $2 \mathrm{n}=39$ was about 25.5 per cent (Table 5).

Table 5. Number of plants with different chromosome numbers in the $F_{1}$ of the cross, triple monosomics $\times$ normal plant, in Chinese Spring wheat

\begin{tabular}{|c|c|c|c|c|c|}
\hline \multirow{2}{*}{$\begin{array}{l}\text { Cross } \\
\text { combinations } \\
\text { (우) (令) }\end{array}$} & \multicolumn{4}{|c|}{ Chromosome numbers } & \multirow{2}{*}{ Total } \\
\hline & 39 & 40 & 41 & 42 & \\
\hline$\underset{(\%)}{\operatorname{m} 1 \mathrm{Am} 2 \mathrm{Bm} 4 \mathrm{~A}} \times$ Normal & $\begin{array}{l}11 \\
(31.4)\end{array}$ & $\begin{array}{l}13 \\
(37.1)\end{array}$ & $\begin{array}{l}10 \\
(28.6)\end{array}$ & $\stackrel{1}{(2.9)}$ & $\begin{array}{r}35 \\
(100)\end{array}$ \\
\hline$\underset{(\%)}{\operatorname{m} 1 \mathrm{Am} 2 \mathrm{Bm} 7 \mathrm{~A}} \times$ Normal & $\begin{array}{l}12 \\
(23.5)\end{array}$ & $\begin{array}{l}16 \\
(31.4)\end{array}$ & $\begin{array}{l}14 \\
(27.5)\end{array}$ & $\begin{array}{l}9 \\
(17.6)\end{array}$ & $\begin{array}{c}51 \\
(100)\end{array}$ \\
\hline$\underset{(\%)}{\operatorname{m} 4 \mathrm{Am} 5 \mathrm{Am} 6 \mathrm{~A}} \times$ Normal & $\begin{array}{l}10 \\
(27.0)\end{array}$ & $\begin{array}{l}15 \\
(40.6)\end{array}$ & $\begin{array}{c}8 \\
(21.6)\end{array}$ & $\begin{array}{c}4 \\
(10.8)\end{array}$ & $\begin{array}{r}37 \\
(100)\end{array}$ \\
\hline$\underset{(\%)}{\operatorname{m} 1 A m 3 A m 7 A} \times$ Normal & $\begin{array}{l}11 \\
(22.9)\end{array}$ & $\begin{array}{l}17 \\
(35.4)\end{array}$ & $\begin{array}{l}15 \\
(31.3)\end{array}$ & $\begin{array}{c}5 \\
(10.4)\end{array}$ & $\begin{array}{r}48 \\
(100)\end{array}$ \\
\hline$\underset{(\%)}{\operatorname{mlAm} 6 \operatorname{Am} 7 \mathrm{~A}} \times$ Normal & $\begin{array}{l}13 \\
(25.0)\end{array}$ & $\begin{array}{l}19 \\
(36.5)\end{array}$ & $\begin{array}{l}13 \\
(25.0)\end{array}$ & $\begin{array}{l}7 \\
(13.5)\end{array}$ & $\begin{array}{c}52 \\
(100)\end{array}$ \\
\hline $\begin{array}{c}\text { Total } \\
(\%)\end{array}$ & $\begin{array}{l}57 \\
(25.5)\end{array}$ & $\begin{array}{l}80 \\
(35.9)\end{array}$ & $\begin{array}{l}60 \\
(26.9)\end{array}$ & $\stackrel{26}{(11.7)}$ & $\begin{array}{l}223 \\
(100)\end{array}$ \\
\hline
\end{tabular}

All 39-chromosome plants showed a chromosome configuration of $18_{\text {II }}+3_{\text {I }}$ in meiosis and strongly resembled morphologically, particularly spike shape, to their female parents. Thus, these plants were identified to be the same triple monosomics as the female parent used in the cross.

From the above-mentioned results, it can be concluded that the triple monosomic strains of hexaploid wheat are maintained through their pollination with normal pollen grains and selection of 39-chromosome plants in the progeny.

\section{DISCUSSION}

In spite of deficiency of two chromosomes, the double monosomic plants of hexaploid wheat were hardly distinguishable from the normal plant in their size, vigor and fertility. Even in the triple monosomics which have three kinds of chromosomes in single dose, vigor and fertility were not so greatly reduced as in nullisomics. This fact suggests that genetic balance necessary for normal plant development is maintained in the hypoaneuploids deficient for two to three non-homologous chromosomes.

In the $F_{1}$ of reciprocal crosses between double monosomics and nullisomics plants 
with 39 chromosomes were obtained. This fact indicates that 19-chromosome gametes produced from the double monosomics, in both pollen and egg, were functional in fertilization. Double nullisomics, which have 19 chromosome pairs, producing constantly 19-chromosome gametes, were mostly sterile in both sexual organs (Shigenaga 1963). Those facts strongly indicate that the development and/or function of gametes are seriously affected by the somatic chromosome constitution of a plant that produces the gametes.

Germination rate of $F_{1}$ seeds obtained from the cross, double monosomics (우) $\times$ nullisomics ( $\hat{o}$ ), was higher than that of the reciprocal cross. In $F_{1}$ of the cross, nullisomics $($ 우 $) \times$ double monosomics $(\hat{o})$, the 41 -chromosome plants were obtained at the frequency of about 84 per cent (Table 3). Accordingly, a most part of the progeny is considered to have been produced by union of the 20-chromosome female gamete from nullisomics to 21-chromosome male gamete from double monosomics. On the other hand, about a half of the $F_{1}$ progeny of the cross, double monosomics $($ o $) \times$ nullisomics ( $\uparrow)$, had a chromosome number $2 \mathrm{n}=39$; they must have derived from union of the 19chromosome female gamete from double monosomics to 20-chromosome male gamete from nullisomics (Table 3). These facts suggest that germination ability of the $F_{1}$ seeds is largely dependent upon the chromosome constitution or genetic balance of the female parent, and less affected by that of the seeds themselves.

Double monosomic plants produced three kinds of gametes with 19,20 or 21 chromosomes in both male and female side. Among them pollen grains with 21 chromosomes showed the highest frequency of fertilization (Table 3), probably due to certation, i.e., 21-chromosome pollen has some advantage in fertilization over the other types of male gametes. In the female side, however, 19-chromosome eggs were more frequently fertilized than the others. This phenomenon is similar to that the 20-chromosome eggs are more frequently fertilized than the 21-chromosome ones in monosomics. Sears (1958) has pointed out that the higher frequency of fertilization of 20- than 21-chromosome eggs in monosomics is related to elimination of a lagging chromosome at meiotic telophase I in embryosac mother cells. A similar chromosome behavior can be reasonably assumed in megasporogenesis on the double monosomics.

In $F_{1}$ of the cross, triple monosomics $($ ㅇ $) \times$ normal plant $(\hat{o})$, plants with the least chromosome number in expectation, i.e. $2 \mathrm{n}=39$, were obtained at a frequency of 26 per cent. The frequency is remarkably higher than that expected, indicating a high frequency of univalent elimination during megasporogenesis in triple monosomics as in single or double monosomics.

\section{SUMMARY}

1. Eight kinds of double monosomics and five of triple monosomics were obtained by systematic procedures in a variety Chinese Spring of common wheat, Triticum aestivum ssp. vulgare.

2. Double monosomics $\left(19_{\mathbf{I}}+2_{\mathrm{I}}\right)$ were obtained by crossing two different nullisomics $\left(20_{\mathbf{I}}\right)$. Triple monosomics $\left(18_{\mathbf{I}}+3_{\mathrm{I}}\right)$ were produced by crossing these double monosomics to third nullisomics. 
3. Plants of the double monosomics were hardly distinguishable from normal disomic plants in size, vigor and fertility. The triple monosomics had high fertility necessary for selfing and crossing, though they showed in general reduced size, vigor and fertility.

4. In progenies of the crosses, double monosomics $($ + $) \times$ nullisomics $(\hat{o})$, plants with the least chromosome number in expectation, i.e. $2 \mathrm{n}=39$, were obtained at the frequencies between 45 and 54 per cent. In the reciprocal cross, however, their frequency was only 4 per cent.

5. Apparently the double monosomics produced three kinds of gametes with 19,20 or 21 chromosomes. The above results demonstrate that the eggs with 19 chromosomes were more frequently fertilized than those with 20 or 21 chromosomes.

6. For the maintenance of triple monosomic strains, crosses between triple monosomics (우) and normal plants (令) were made; $F_{1}$ 's obtained had 39 to 42 chromosomes. The 39 -chromosome plants appeared at a frequency of 25.5 per cent and showed the $18_{\text {II }}+3_{\text {I }}$ chromosome configuration at meiotic metaphase I, which indicated that they were triple monosomic.

7. It was concluded from the results of the present investigation that the 18-chromosome female gametes produced from triple monosomics were functional in fertilization.

\section{ACKNOWLEDGMENT}

This work was started in Prof. A. Mochizuki's Laboratory, Hyogo Agricultural College, which has been changed recently to the Faculty of Agriculture, Kobe University. The author wishes to express his deepest thanks to Prof. A. Mochizuki for his kind guidance and valuable suggestions during the course of this investigation. The work has been continued and completed in the Experimental Farm, Kyoto University. The author also expresses his sincere thanks to Prof. K. Shakudo, Laboratory of Plant Breeding, Kyoto University and to Prof. K. Tsunewaki, Laboratory of Genetics, Kyoto University for their criticisms and continuous encouragements. He also acknowledges his deep indebtedness to Prof. A. Fukuda, the Experimental Farm, Kyoto University and Dr. H. Ono, Laboratory of Genetics, Kobe University for their helps in many ways to carry out this investigation. Monosomic series of Chinese Spring wheat was obtained from Dr. M. Okamoto, Shiga Agricultural College, Dr. E. R. Sears, University of Missouri, Missouri, U.S. A., Dr. B. C. Jenkins, University of Manitoba, Winnipeg, Canada (presently, World Seeds, Inc., U.S. A.) and Dr. M. Muramatsu, Kihara Institute for Biological Research. Finally the author expresses his hearty thanks to all of them.

\section{LITERATURE CITED}

Chapman, V., and R. Riley, 1966 The allocation of the chromosomes of Triticum aestivum to the A and $\mathrm{B}$ genomes and evidence on genome structure. Can. J. Genet. Cytol. 8: 57-63.

Kihara, H., und S. Matsumura, 1942 Ueber die Univalenten-elimination in den vershieden-chromosomigen Nachkommen des pentaploiden Triticum-Bastards. Japan. J. Botany 12: 225-236.

Mochizuki, A., and S. Shigenaga, 1964 Extraction of B genome from hexaploid wheat. Sci. Rep. Hyogo Univ. Agr. 6-2, Ser.: Agr. Biol. 49-52. 
Okamoto, M., 1962 Identification of the chromosomes of common wheat belonging to the A and B genomes. Can. J. Genet. Cytol. 4: 31-37.

Sears, E. R., 1954 The aneuploids of common wheat. Mo. Agr. Exp. Sta. Res. Bull. 572: 1-58.

Seasr, E. R., 1958 The aneuploids of common wheat. Proc. 1 st Int. Wheat Genet. Symp., 221-228.

Shigenaga, S., 1963 Cytogenetical studies on double monosomics, nulli-monosomics and double nullisomics in wheat. Sci. Rep. Hyogo Univ. Agr. 6-1, Ser.: Agr. Biol. 28-35.

Wakakuwa, Sh., 1929 Variation of chromosome numbers among $F_{2^{-}}$and $F_{3}$-progenies in the crosses between two dwarf wheat plants. Japan. J. Genetics 4: 187-197. 